\title{
遠隔で行う他動運動による在宅手首リハビリシステムの研究*
}

修

\author{
震**, 留 \\ 滄 海**, 北 川 \\ 能**, \\ 塚 越 秀 行**, 小西 健一郎***
}

\section{Study on At-home Wrist Rehabilitation System by Remote Passive Exercise}

\author{
Zhen XIU, Canghai LIU, Ato KITAGAWA, Hideyuki TSUKAGOSHI, Kenichiro KONISHI
}

\begin{abstract}
This study focuses on the at-home wrist rehabilitation system aiming to achieve the situation where home-stay patients can accept rehabilitation from therapist in clinic. As the first stage, this paper discusses the development of the wrist rehabilitation by remote passive exercise for stroke patients. Firstly, based on the dynamic model of passive exercise, rehabilitation by remote passive exercise is proposed. Secondly, pneumatic pseudo-therapist which can realize the therapist's rehabilitation actions and pneumatic pseudo-patient which can realize the patient's resistance are designed and fabricated. Finally, based on the experimental result in clinic, the validity of the rehabilitation system developed in this paper is verified.
\end{abstract}

Key words : Pneumatics, Medical and Welfare Assistance, Biomechanics,Tele-Robotics, Human-Robot-Interaction

\section{1. 緒言}

片麻痺患者の治療において, 脳や脊髄といった中枢神経 系の可塑性を活用し，麻痺した手足に効率の良い効果的刺 激や環境を与えれば，患者自身の脳の潜在能力が引き出さ れ，自分で動けるようになると考えられている，そのため， 身体運動を生成するリハビリが有効とされている1). しか し，リハビリを指導する理学療法士の人数は全国の理学療 法関連施設を満遍なく満たすほど十分ではないのが現状で ある2). 一方, 患者, 特に高齢患者にとっては, 一般の通 院リハビリよりも理学療法士が患者宅を訪れる訪問リハビ リの方が望ましい. しかし，訪問リハビリの実施はただで さえ十分ではない理学療法士数の問題をより深刻化させる ため, (1)訪問リハビリの実施率が低いこと, (2)患者宅まで の往復時間がかかるため, 十分な治療時間がないこと, (3) ほとんど問題視されていないが, 理学療法士は過剩な負担 を背負っていること，(4)医療の地域格差が生じること，な どの問題を生むこととなっている. この問題に対して, 従 来は身体運動を生成するための様々なリハビリ機器が開発 されてきた ${ }^{3)}$.4). また, 理学療法士による遠隔リハビリを目 指した映像による患者の症状把握の研究も行われている ${ }^{5)}$.

そこで本研究では, 片麻痺患者の手首のリハビリを対象

*平成21年 5 月 14 日 原稿受付

**東京工業大学大学院理工学研究科

(所在地 : 東京都目黒区大岡山 2-12-1)

(E-mail : kitagawa@cm.ctrl.titech.ac.jp)

***真岡中央クリニックリハビリ科

(所在地 : 栃木県真岡市上高間木 $2-24-5$ )
として取り上げ，患者が訪問リハビリを受けると同等のリ ハビリが実現できる「在宅手首リハビリシステム」を提案 する ${ }^{6)}$ ここてで, 「在宅」とはクリニックに居る理学療法士に よる治療を患者が在宅のまま遠隔で受けることを意味する. このシステムができれば, 理学療法士の不足が緩和でき るだけでなく, 高齢患者は通院に伴う肉体的, 精神的, 経 済的負担から解放されることが期待できる，さらに，医療 施設が整っていない過疎地に散在する高齢患者でも在宅で の理学療法士によるリハビリが可能になる.

本論文は在宅手首リハビリシステム実現の第 1 段階とし て, 遠隔で行う他動運動によるリハビリが可能な在宅手首 リハビリシステムを開発する。まず患者の手首の他動運動 の力学モデルをもとに, 遠隔で行う他動運動によるリハビ リを提案する. 次に, 理学療法士の動作を再現できる疑似 療法士と患者の抵抗を再現できる疑似患者からなる空気圧 駆動の在宅手首リハビリシステムを試作する. 最後に患者 を被験者とした検証実験を行い, 試作したシステムが遠隔 で行う他動運動が可能な在宅手首リハビリシステムとして の機能を有することを明らかにする.

\section{2. 他動運動による在宅手首リハビリ}

\section{1 他動運動の特徵}

リハビリ療法には表 1 に示すように, 他動運動, 自動運 動がある7). 自動運動は, 患者自身の筋力で動かす運動で あり, 患者の脳から出る命令により障害部位を動かすので, 遠心性および求心性神経経路が刺激され, 患者の脳の潜在 能力が引き出される. 一方, 本論文が対象としている他動 運動は, 患者が他動的に動かされる運動であり, その反復 
により，各関節の角度変化に伴う筋肉の伸縮活動信号を脳 に送り込むことができ, 求心性神経経路が刺激される。本 研究が目指すのは在宅手首リハビリであり, 理学療法士と 患者は互いに直接触れないが, 両者とも触れているように 感じることが重要であるため, リハビリの際の両者に働く 力の関係を詳細に検討する必要がある。 そこで次節では手 首の他動運動の力学モデルを検討する.

Table 1 Classification of rehabilitation exercise

\begin{tabular}{|l|c|c|}
\hline & Explanation & Effective point \\
\hline Passive exercise & $\begin{array}{c}\text { Moving joints by } \\
\text { external force }\end{array}$ & $\begin{array}{c}\text { Afferent nerve } \\
\text { stimulation }\end{array}$ \\
\hline Active exercise & $\begin{array}{c}\text { Moving joints by } \\
\text { mind with assistance } \\
\text { or resistance }\end{array}$ & $\begin{array}{c}\text { Efferent and afferent } \\
\text { nerve stimulation }\end{array}$ \\
\hline
\end{tabular}

\section{2 手首の他動運動の力学モデル}

健常者の手首には関節を曲げ伸ばしする伸筋及び屈筋が あり，手首関節は張力が大きい側へ曲がる．筋肉は力発生 器と抵抗の二つの機能を持つ特殊なアクチュエータと考え ることができる．健常者の掌屈・背屈の手首曲げのモデル を図 1 に示す ${ }^{8)}$. Uは手首筋肉の力発生器の発生する力であ り，抵抗に関する $K, C$ 手首の弾性および粘性を表すパラ メータである．健常者の場合， $U, K, C$ 筋活動レベルに よって変化し，さらにK,CはUによって変化する。した がって, 力発生器が発生する関節卜ルクを $\tau_{u}$, 手首関節を 軸とする手の慣性モーメントを $I$, 手首の角度を $\theta$, その自 由位置での角度を $\theta_{0}$ すると, 運動方程式は式(1)のように表 される.

$$
\tau_{u}=K\left(\theta-\theta_{0}\right)+\dot{C}+\ddot{\theta} \ddot{\theta}
$$

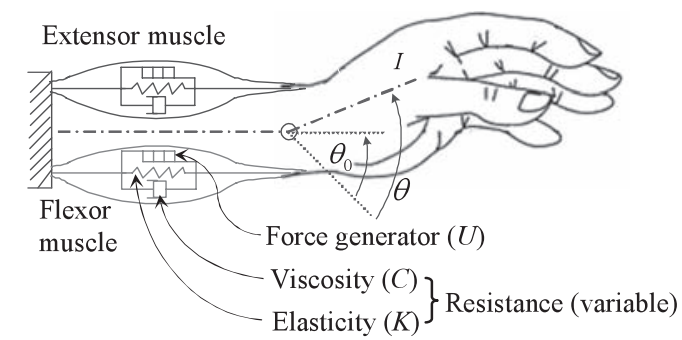

Fig. 1 Dynamic model of able-bodied person's wrist

一方, 本研究で対象とする片麻痺患者は, 筋活動レベル が非常に低くなっており, 力発生器は衰弱もしくは機能し ていないのでUは小さく, 手首の抵抗 $K, C$ はきき. そし てその抵抗の大きさは患者の意思では変わらなくなってい る.ささに, 理学療法士はまず患者に「力を抜いてくださ い」と言ってから他動運動によるリハビリを始めるため, 一般に他動運動を行っている状態では患者の力発生器は機 能していない. そのため, 他動運動によるリハビリの際,
理学療法士が患者の筋肉の力発生器の代わりに患者の手首 に力を加える必要がある. そこで, 本研究では図 1 に示す 健常者の手首の力学モデルを参考に, 患者の手首とその他 動運動によるリハビリの力学モデルとして図 2 に示すモデ ルを用いる. したがって, 理学療法士が患者に与えるトル クを $\tau_{t h}$ とすると, この場合の運動方程式は式(2)のように表 される.

$$
\tau_{t h}=K\left(\theta-\theta_{0}\right)+\dot{C} \dot{\theta}+\ddot{I \theta}
$$

図 2 の上図のリハビリ動作を力学モデルで表現すると, 下図のようになり, 患者の手首は健常者に比べて力発生器 がないため受動的と見なせ，また抵抗 $K, C$ 短時間ではあ まり変化しないものになっている，したがって，患者の手 首を対象とする遠隔リハビリは十分可能と考えられる.

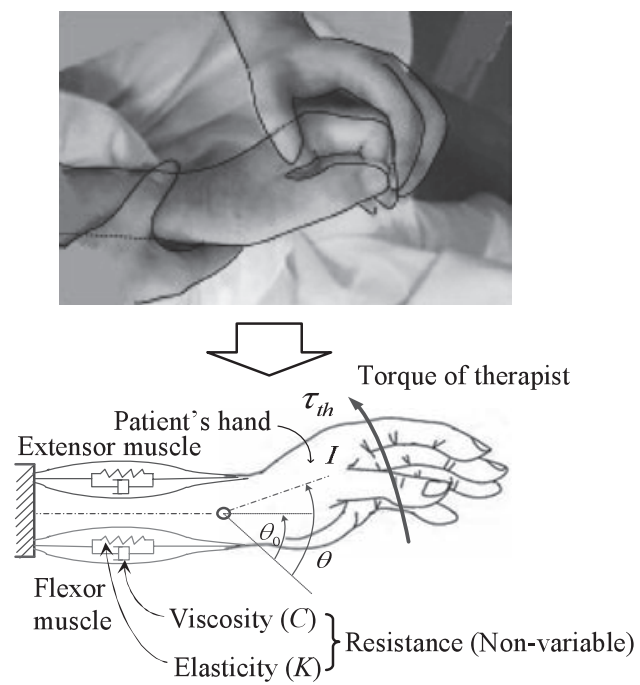

Fig. 2 Dynamic model of passive exercise with patient

\section{3 遠隔で行う他動運動による在宅手首リハビリ}

他動運動によるリハビリにおいては, 理学療法士は患者 からの反力を感じながら治療を行うことが重要である。さ らに理学療法士と患者が話しながら行うこと, すなわちコ ミュニケーションは患者や家族に安心感を与えている.

そこで，本論文では，図 2 に示した患者手首の他動運動 の力学モデルをもとに, 理学療法士に代わって力を発生す る「疑似療法士 (Pseudo-therapist)」をスレーブとし，患 者の手首に代わって抵抗を発生する「疑似患者（Pseudopatient)」をマスタとしたマスタ・スレーブシステムを用 いた遠隔で行う他動運動による在宅手首リハビリを提案す る.この方法により, 患者の筋肉の力発生器の代わりに理 学療法士が疑似療法士を通じて患者の手首に力を加えるこ とができる，一方，患者は疑似患者を通じて患者の手首の 抵抗（硬さ）を理学療法士に伝えることができる. 図 3 は その概念図であり, 図の上半分はクリニックにある疑似患 者とそれを操作する理学療法士を表しており，下半分は患 者宅にある疑似療法士と治療を受ける患者を表している。 さらに図の左半分の破線枠内で発生した力が図の右半分の 
破線枠内の抵抗に加えられることも表している．結果とし て, 疑似療法士が理学療法士の力を再現し, 疑似患者が患 者の抵抗を再現することになる．これによって図 2 と同様 な動作を遠隔で穾現することができる.

また，在宅患者と理学療法士の間の情報伝達の手段とし ては，どこでも利用できる一般のインターネットを利用す れば，リハビリに重要なコミュニケーションもインター ネットを経由した映像と音声の通信によって容易に実現で きる.
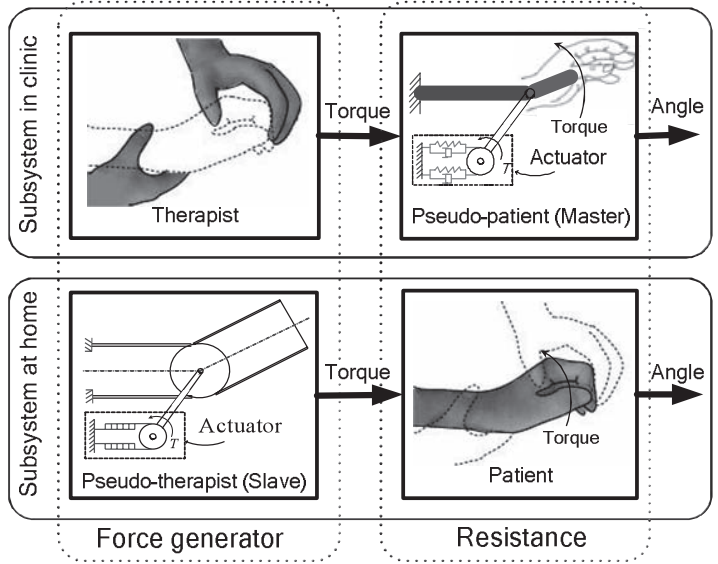

Fig. 3 Concept of rehabilitation by remote passive exercise

\section{3. 在宅手首リハビリシステムの試作}

理学療法士の力を再現する疑似療法士と患者の抵抗を再 現する疑似患者を用いれば在宅手首リハビリが可能となる ことを前章で示した. 本章では, 疑似患者と疑似療法士の設 計試作にあたり，両者にどのようなリハビリ動作が必要で あるかを知るため，まず理学療法士のリハビリ動作を詳細 に検討し，それをもとに疑似患者と疑似療法士を試作する。

\section{1 理学療法士のリハビリ動作}

手首のリハビリには, 図 $4(\mathrm{a}),(\mathrm{b})$ に示す掌屈・背屈 (Dorsal/Palmar flexion) と図 4 (c)，(d)に示す橈屈・尺屈 （Radial/Ulnar flexion）という 4 つの基本動作がある.

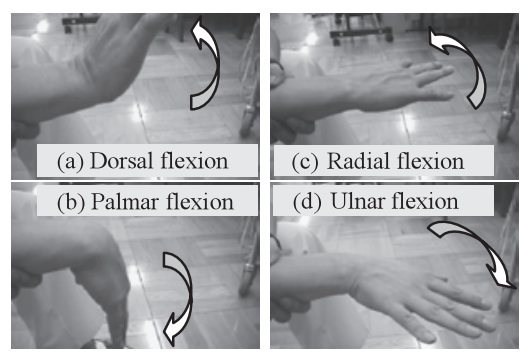

Fig. 4 Basic motions for wrist rehabilitation

手首のリハビリは掌を開いて指を反らせて行うと手首関 節周辺の筋肉が緊張して神経を刺激しやすくなるので効果
的となる. 図 $5(\mathrm{a})$ は理学療法士が掌を開いた状態でリハビ リを行う様子を示している.一方,多くの片麻疩患者は自力 では掌を開けられないため, 理学療法士はまず四 5(b)(1) 一 (2)のように患者の閉じた掌を開いて指を反らせる必要があ る。そこで本論文ではリハビリ動作としては掌屈・背屈動 作を対象とし, 疑似療法士の試作に当たっては, まず掌を開 き，さらに指を反らせた状態に保つ構造とすることにした。

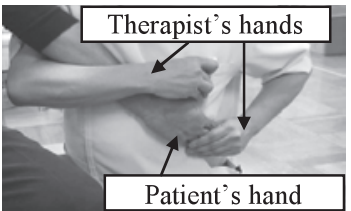

(a) Rehabilitation scene
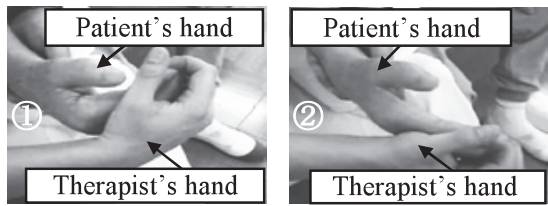

(b) Opening process of palm

Fig. 5 Wrist rehabilitation with palm opening

\section{2 疑似患者と疑似療法士の構成}

試作したマス夕となる疑似患者を図 6 に示す，疑似患者 は手首形にし，表面を人間の皮膚と似た弾力のある手首形 ゴムカバー（指先から肘までの形を再現したもの）で覆っ た. 図 6(a)のように理学療法士がこれを両手で抱えて操作 する際，あたかも実際の手首を抱えてリハビリを行ってい るように感じさせるためである。この疑似患者の手首形力 バーの中は図 6(b)に示すような構造になっており，圧力制 御によってトルク制御が容易に行える空気圧ロータリーア クチュエータ（黑田精工(侏社製）を手首関節に設置してト ルクを再現する.アクチュエータの出力軸に回転型ポテン

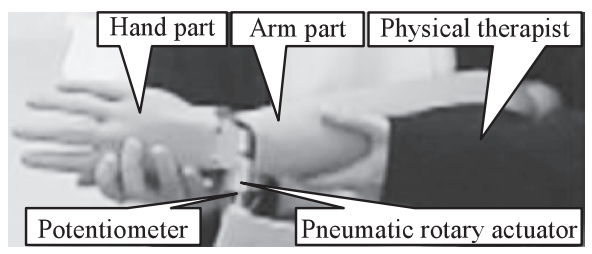

(a) Photo

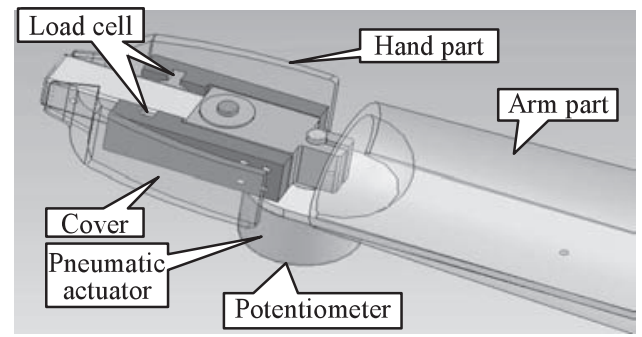

(b) Mechanical structure

Fig. 6 Pseudo-patient device 
ショメータと自作のトルクセンサを取り付け，回転角度と トルクを測定する。 トルクセンサは図 6(b)のように，超小 型圧縮型ロードセル (LSM社製) を 1 自由度の支柱の両側 に一個ずつ固定したものである.

一方，患者の手首を動かすスレーブとなる疑似療法士は 装着の利便性を考え，図 7 (a)に示すように，患者の肘より 先が簡単に入るよう凹形にし, 手首は腕ホルダと掌ホルダ で固定するようにした，手首関節の駆動は安全性を考慮し てコンプライアンスが大きい空気圧ロータリーアクチュ エータで行い, その角度とトルクの計測は疑似患者と同様 に行った，患者手首の可動範囲を考慮し，空気圧ロー夕 リーアクチュエータの摇動範囲は $90^{\circ}$ ののを選定した. さらに，通常硬く閉じてしまっている患者の掌を開くため， 疑似療法士の先端には患者の指を挟んで開く指ホルダを取 り付けた。これは $180^{\circ}$ 回転可能な小型空気圧ロータリーア クチュエータで駆動され, 図 5(b)に示した理学療法士のよ うに患者の掌を開くものである．指を開く際，指の回転中 心は変化するので，指を挟む部分にはリニアスライドを設 置し指に負担をかけないようにした。 また患者の親指を反 らすため, 図 7 (b)に示すように親指をマジックテープで上 方に引っ張って固定できるようにした. なお, 柔らかく固定 するため各ホルダ部分にはエアバッグとスポンジを詰めた.

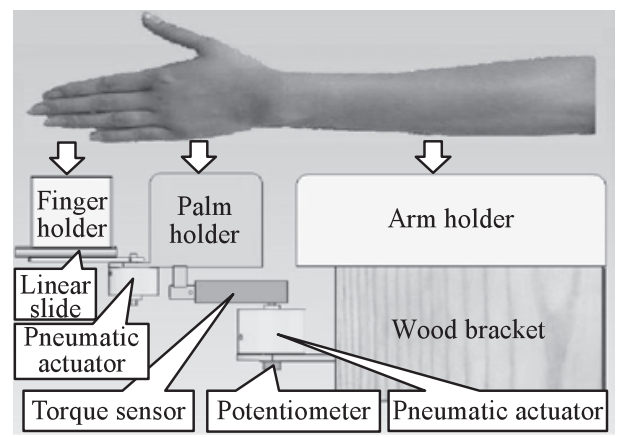

(a) Mechanical structure

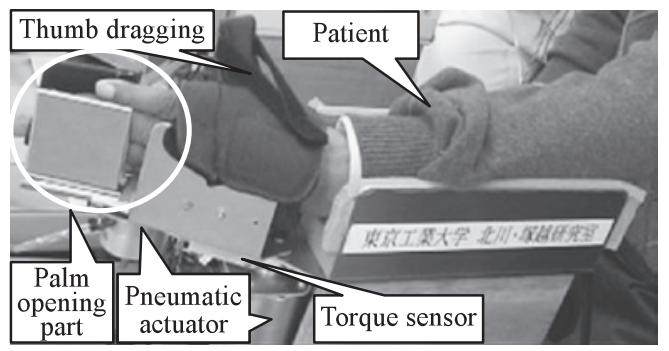

(b) Photo

Fig. 7 Pseudo-therapist device

図 8 は疑似患者および疑似療法士の空気圧ロータリーア クチュエータの駆動回路である．患者の反力を再現するた め疑似患者と疑似療法士の制御には力帰還型バイラテラル 制御9)を用いた。両者の制御式は次の 2 式で表される.

$$
\tau_{m}=G_{m c}(s) \cdot\left(\tau_{t h}-\tau_{p}\right)
$$

$$
\tau_{s}=G_{s c}(s) \cdot\left(\theta_{m}-\theta_{s}\right)
$$
ここで， $\tau_{m}$ と $\tau_{s}$ は疑似患者と疑似療法士のアクチュエータ の駆動トルク， $\tau_{t h}$ は理学療法士が疑似患者へ加えるトルク， $\tau_{p}$ は疑似療法士が患者へ加えるトルク， $\theta_{m}$ と $\theta_{s}$ は疑似患者 と疑似療法士の回転角度, $G_{m c}(s)$ と $G_{s c}(s)$ は疑似患者と疑似 療法士のPIDコントローラの伝達関数である. アクチュエー 夕のベーン両側の部屋の圧力 $p_{m 1}, p_{m 2}$ および $p_{s 1}, p_{s 2}$ をそれぞ れ 2 個の電空レギュレータ (SMC(株)社製) で制御すること により, 疑似患者の場合はトルクを, 疑似療法士の場合は角 度を制御している.なお図が煩雑にならないよう, アクチュ エータに接続されているその他の部分は記述を省略した。

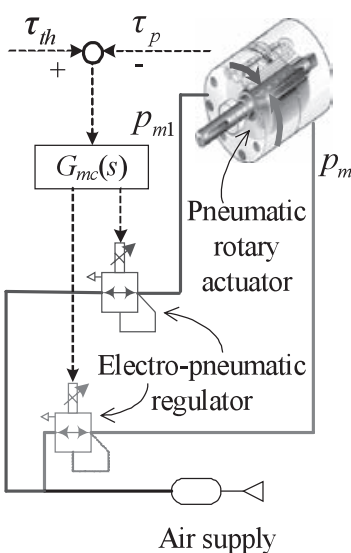

(a) Pseudo-patient

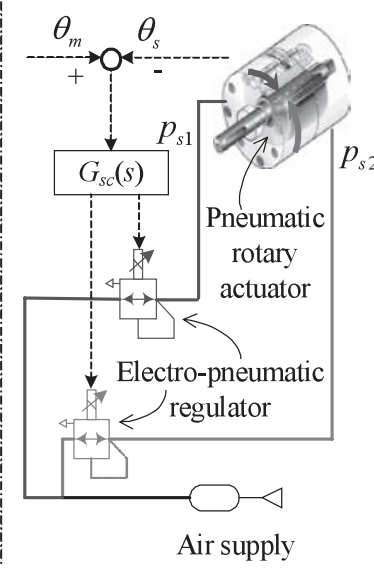

(b) Pseudo-therapist
Fig. 8 Pneumatic circuit

\section{4. 患者の手首による検証実験}

試作した在宅手首リハビリシステムを用いた遠隔の他動 運動による手首リハビリの可能性について, 患者を被験者 にした検証実験をクリニックにおいて行った. 被験者と なった患者のプロフィールを表 2 に示す，麻痺ステージは Brunnstrom stage III以上であるので, 随意的な伸展は不能 になっている10).

Table 2 Profile of the patient

\begin{tabular}{|l|l|}
\hline Medical history & Being left-paralyzed from 2002 \\
\hline Sex/Age & Male/62 \\
\hline $\begin{array}{l}\text { Brunnstrom } \\
\text { stage }\end{array}$ & $\begin{array}{l}\text { Left upper limbs (III) } \\
\text { Left lower limbs (IV) } \\
\text { Left finger (III) }\end{array}$ \\
\hline Range of motion & Dorsal $\left(40^{\circ}\right)$ Palmar $\left(60^{\circ}\right)$ \\
\hline \multirow{3}{*}{ Others } & $\begin{array}{l}\text { Conscious impairment (+) } \\
\text { Sense impairment (+) } \\
\text { Spastic muscle } \\
\text { Hearing (able) } \\
\text { Talking (able) }\end{array}$ \\
\hline
\end{tabular}




\section{1 検証実験：その 1}

最初に，疑似患者と疑似療法士をインターネットを介さ ずに直結した実験（検証実験：その1）を行った.

理学療法士の動作をできる限り再現するため, 理学療法 士と同様，次のような手順で行った（1)时より先を凹型の 疑似療法士にセットし, 手首より先は疑似療法士の可動部 (図 7 のPalm holderおよびFinger holder) にエアバッグで 固定する. (2)疑似療法士のFinger holderを回転させて親指 以外の指を反らせた位置まで開き，さらに親指も反らせた 位置にマジックテープで固定する. (3)理学療法士は疑似患 者の前腕部分と掌部分を両手で抱えて操作し，患者の手首 の抵抗を感じながらリハビリを行う。

手首の掌屈・背屈動作によるリハビリを行った際の疑似 患者と疑似療法士の角度とトルクの測定結果を図 9 に示す。 縦軸の角度は，疑似療法士のPalm Holderが直線位置から 掌屈側に $45^{\circ}$ 曲がったところを原点とし, 背屈側に向かう 角度である，疑似療法士は疑似患者の角度によく追従し， 疑似患者は患者の手首の抵抗(トルク)をよく再現している.
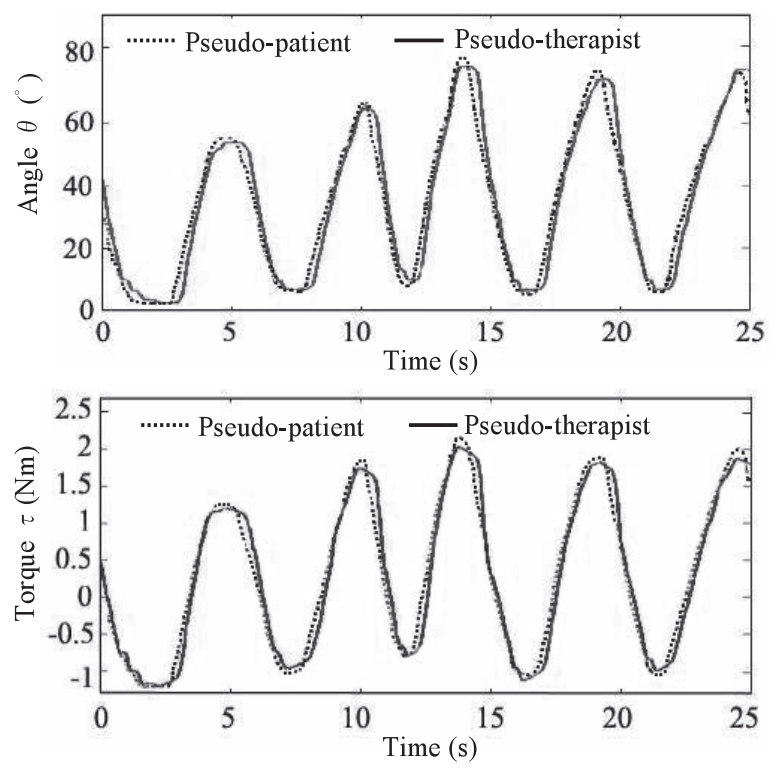

Fig. 9 Experimental result in clinic (1)

さらに 2.2 節の図 2 に示した患者の手首とその他動運動に よるリハビリの力学モデルの妥当性を確認するため, 図 9 の結果をもとにモデルの同定を行った。予測誤差法を用い, $K=0.0437, C=0.00132, I=0.108 \times 10^{-4}$ の同定結果を得た. また図 9 から得られる患者（疑似療法士）の角度とトルク の関係を図10に書き直し，K值と比較した結果，他動運動 によるリハビリにおいては抵抗のうち弾性が支配的であり， 2 章で述べた力学モデルにより手首が近似的に表現できる ことが分かった。

\section{2 検証実験 : その 2}

本研究の目的は在宅手首リハビリシステムの実現にある. そこで疑似患者と疑似療法士の間にインターネットを模擬

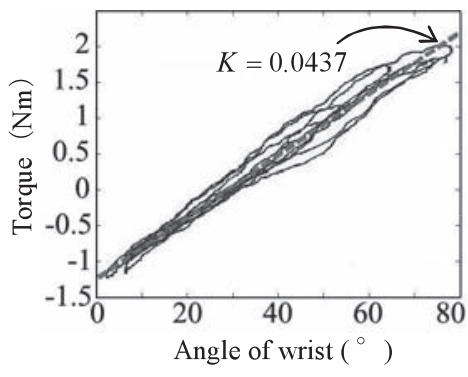

Fig. 10 Relation between torque and angle of patient's wrist

した通信環境を構築し ${ }^{11}$ ， 実験（検証実験：その 2 ）を 行った.

手首の掌屈・背屈動作によるリハビリを行った際の疑似 患者と疑似療法士の角度とトルクの結果を図11に示す。図 11の結果は図 9 に比べてインターネットに起因する時間遅 れが見られるものの，疑似療法士は疑似患者の角度にほほ 追従し, 疑似患者は患者の手首の抵抗をほぼ再現している.
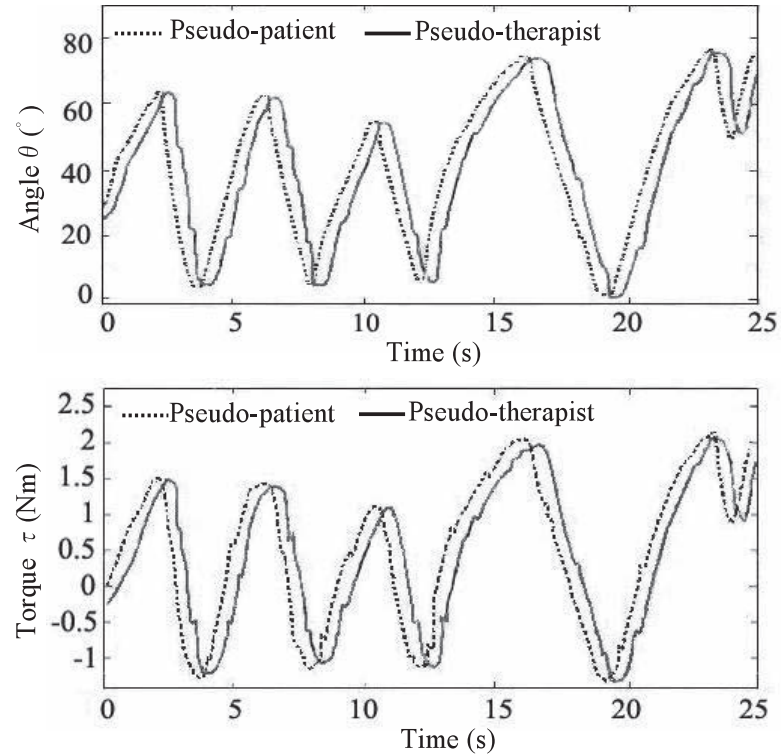

Fig. 11 Experimental result in clinic (2)

\section{3 考 察}

図 9 および図11に示したように，試作した在宅手首リハ ビリシステムは遠隔の他動運動による手首リハビリに最低 限必要な基本的機能を有することが分かった．検証実験 1 および 2 を通じて得られた患者の感想と理学療法士の意見 は以下のようにまとめられる.

患者：

(1) 装着が簡単で，エアバッグとスポンジにより腕と手 のひらと指が痛みなく固定でき，リハビリの際にずれ や痛みがなかった。

（2）指を回転して反らせる際に指に負担がかからず，理 学療法士のように指を開く感じがした。親指も気持ち よく反ってくれた 
(3) 疑似療法士によるリハビリは理学療法士が直接行う 場合とあまり変わらず，違和感はなかった。

(4) 一定の角度内でしか動かないので安心.

（5）通院しなくても自宅で理学療法士のリハビリが受け られるようになれば私も家族も嬉しい. 理学療法士 :

（1）形や感触が人体に似ているので操作し易い

（2）疑似患者から患者の手首の反力が感じ取れたので他 動運動によるリハビリを行っているという感覚があっ た。

（3）患者の家を訪問しなくても患者の症状が感じられ， 他動運動によるリハビリができて便利である.

以上のように試作したシステムは遠隔の他動運動が可能 な在宅手首リハビリシステムとしての機能を有することが 分かった。

他動運動によるリハビリでは，外部からの刺激情報は末 梢神経を経由して脳や脊髄などの中枢神経へ伝わるが，そ のとき刺激情報を受け取った神経網内の細胞が何らかの反 応を起こし神経回路が回復することを目的としている．実 際に被験者となった患者は，手首リハビリを開始してしば らく後には麻痺した左側の上半肢がビクビクする感覚が あったと述べた，理学療法士は，これは手首のリハビリが 神経を刺激した結果であり, 神経回路が回復の方向に向か う可能性があることを示すものと述べた．さらに，退院後 の通院あるいは自宅療養が中心である維持期の患者のリハ ビリに本システムを用いれば，理学療法士は入院中の回復 期の患者のリハビリをより多く行える点が有効であるとも 述べた。

本論文では北京と東京間という国際間のインターネット で発生する比較的大きな約 0.3 秒前後の時間遅れを仮想的な 通信環境として使った．そのため, 理学療法士は反力に関 して若干の時間ずれの違和感を感じたと述べた。 しかしこ の問題についてはインターネット通信技術の発展とともに 解消される方向に向かうと考えられる.

\section{5. 結言}

本論文は，片麻疩患者の手首リハビリを対象として取り 上げ，遠隔で行う他動運動によるリハビリが可能な在宅手 首リハビリシステムを開発した。 まず理学療法士の動作を 詳細に検討し，これを再現できる疑似患者と疑似療法士か らなる空気圧駆動の在宅手首リハビリシステムを試作した. 次に患者を被験者とした検証実験を行い，患者ならびに理 学療法士の評価をもとに, 試作したシステムが遠隔の他動
運動が可能な在宅手首リハビリシステムとしての機能を有 することを明らかにした。

本研究は, 遠隔で行う他動運動によるリハビリに続き, 他動運動で得られた手首特性を活用した自動運動によるリ ハビリを検討する，それらの成果をもとに患者が訪問リハ ビリを受けると同等のリハビリができる在宅手首リハビリ システムの実現を目指す。

\section{参 考 文 献}

1) Kottke, F. J.: Therapeutic exercise to develop neuromuscular coordination, Krusen's handbook of physical medicine and rehabilitation, 452/479 (1990)

2 ）佐々英達, 豊田堯, 鮫島健 : 平成18年度診療報酬改定 における緊急要望，全日本病院協会，1／1（2006）

3 ) 安川電機 : ベッドサイド型下肢運動療法装置, 日本メ ディックスリハビリテーション機器・福祉機器, 144/145 (2007)

4 ）宮越浩一, 道免和久：脳卒中片麻痺患者に対する上肢 機能訓練装置の使用経験, リハビリテーション医学, 43-6, 347/352 (2006)

5 ) Yamashita, K., Kawamura, T.: An analysis of a new method for estimating the range of hand motion using tele-rehabilitation, Japanese journal of medical physics, 24-4, 162/168 (2004)

6 ）修震, 塚越秀行, 井戸聞多, 北川能, 留滄海: Internet-based telerehabilitation system for wrist with single-master and multi-slaves, 計測自動制御学会シス テムインテグレーション部門講演会, 785/786（2005）

7 ) Doering, T. J., et al:: Passive and active exercises increase cerebral blood flow velocity in young, healthy individuals, American Journal of Physical Medicine \& Rehabilitation. 77-6, 490/493 (1998)

8 ）伊藤広司，伊藤正美：生体とロボットにおける運動制 御, 計測自動制御学会, 133/146（1991）

9 ) 小林尚登他：ロボット制御の実際, 計測自動制御学会, 228/241 (1997)

10）脳卒中合同ガイドライン委員会 (編) : 脳卒中治療ガ イドライン $2004,228 / 229$ (2004)

11 ) 修震, 北川能, 留滄海, 塚越秀行, 呉平東 : インター ネットを用いた空気圧マスタ・スレーブシステムのバ イラテラル遠隔制御に関する研究, 日本フルードパ ワーシステム学会論文集，44-3，37/42（2009） 